УДК 784.9:785.7

DOI:

Петро Турянський, дочент кафедри народних музичних інструментів та вокалу Дрогобицького державного педагогічного університету імені Івана Франка

Лідія Радевич-Винницька, старший викладач кафедри народних музичних інструментів та вокалу Дрогобицького державного педагогічного університету імені Івана Франка

\title{
РОЛЬ ЕМОЦЙНИХ ЗАСОБІВ У ВИКОНАННІ ВОКАЛЬНО-КАМЕРНОГО ТВОРУ
}

У статті аналізуються різноманітні напрямки роботи, які використовуються у роботі викладача по підготовиі майбутнього вокаліста. Вокальний репертуар відіграє важливу роль в естетичному та артистичному розвитку студента. Досвідчений викладач повинен приділити велику увагу підбору відповідного репертуару. Використовуючи різноманітний, добре підібраний репертуар, студент знайомиться з різними вокальними методиками, музичними стилями і творами. Крім того студент вчиться співати з правильною артикуляцією, вчиться відчувати всі відтінки музичної інтонації, відкриває для себе особливості поезії, покладеної на ноти і в результаті відтворює все це у власному виконанні.

Тому різноманітний $і$ правильно підібраний вокальний репертуар має невичерпні можливості в підготовиі високопрофесійного спеціаліста.

Ключові слова: спів; голос; вокально-камерний репертуар; вокальний потенціал; артистичне виконання; гармонійний розвиток; вокальна підготовка.

Jim. 5.

Petro Turyanskiy, Assosiate Professor of the Folk Musical Instruments and Vocal Singing Department, Drohobych Ivan Franko State Pedagogical University Lidiya Radevych-Vynnytska, Senior Lecturer of the Folk Musical Instruments and Vocal Singing Department, Drohobych Ivan Franko State Pedagogical University

\section{THE ROLE OF EMOTIONAL COMPONENTS IN VOCAL CHAMBER SINGING}

The present paper examines the different ways used in professional training of the future vocalist. Vocal repertoire of the students' training plays a great role in their aesthetic as well as artistic development. It is stressed that vocal repertoire has to be very varied: the diversity of musical works improves musical hearing and taste, develops singing and artistic performance. Thus, an experienced teacher has to pay considerable attention to the selection of appropriate vocal repertoire. By using a varied, well-selected repertoire students familiarize themselves with different singing techniques, music styles and works. Moreover, they learn how to sing with correct articulation, discover the peculiarities of poems transformed into songs, sense all shades of musical intonation and, consequently, recreate them in their own singing performance. Therefore, a varied, appropriately chosen vocal repertoire has inexhaustible opportunities in teaching a highly-professional vocalist.

It has been emphasised on multiple occasions that vocal performance of musical works with varying degrees of emotional charge. Such an approach to voice coaching consists in the idea that as the educator is striving to enhance the quality of his student's voice, he must not deprive the student of a chance to generate sound on his own terms, with a naturally emerging emotional colouring whereby the educator is to assist the student in terms of how to bring out fine shades in the timbre of the vocalist as per specific artistic and emotional assignment pertaining therewith. The article also stresses the fact that chamber vocal performances substantially contributes to the singer's professional development, expands his outlook, enriches him intrinsically, enables him to master new vocal patterns as judging by the singer's manner of performance, his eloquence and the degree of sophistication in musical phrases, the depth of image perception, one may immediately form an opinion on how familiar the singer is with musical literature. It has also been stated that vocal control is typically assumed in the course of working on the artistic image, as the artist is selecting the most suitable means of expression. Thus, from the very first years of vocal training, it is necessary to disclose - to the singer's attention - the concealed properties of tempos, metric lines, musical forms and the architecture of rhythm wherein the dynamics of processes incarnated in music is revealed. It is further highlighted that the emotional stage in the ongoing performance of each vocal work that is being studied in the classroom contributes to the emotional colouration of the sound corresponding with the properties of the work in question. It is particularly important to ensure that the singer obtains and maintains his vibe (emotional disposition) throughout the process - not only during the performance of a musical work within an academic concert but also in the course of primary processing of the said work-i.e., from the very beginning. 
It should be emphasized that a teacher has to show students how correctly to choose emotional components, which will result in the professional performance of their vocal repertoire.

Keywords: singing; voice; vocal and chamber repertoire; vocal potential; artistic performance; harmonious development; vocal preparation.

П остановка проблеми. Вокальні твори камерного репертуару (романси, українські народні пісні, твори українських та сучасних композиторів, зарубіжних класиків) $є$ важливим виховним засобом у морально-естетичному та національному вихованні студентів. Цей репертуар сприяє розвитку і формуванню художнього світогляду, вдосконаленню мистецької майстерності, смаків та запитів молоді, розвитку їхнього внугрішнього світуза допомогою набугтя конкретних знань та вмінь, необхідних для повноцінного сприйняття та відтворення художніх образів, здатності до творчої самореалізації через мистецтво камерного репертуару.

Опрацювання наукових праць, підручників та багаторічний власний досвід роботи у музичнопедагогічному закладі дає можливість проаналізувати значимість вокально-камерних творів у розвитку вокально-технічних та виконавських даних студента.

Аналіз основних досліджень та публікацій. Проблематика статті висвітлювалася в науковометодичних працях таких авторів: О. Бандрівської, Д. Євтушенко, В. Луканіна, Г. Михайлової, Н. МоттЗаболотіна. Проте емоційна складова виконання вокально-камерного твору не була предметом їхньої уваги. В цьому виявляється іï актуальність.

Мета статті полягає у написанні виокреслити значимість вокально-камерного репертуару і його вплив на розвиток вокально-технічних особливостей майбутнього педагога-музиканта.

Виклад основного матеріалу. Популярність виконання вокально-камерних творів з кінця XIX століття надала можливість співакам, у яких не було від природи належних вокальних даних, а саме: сили звуку, повного діапазону голосу, фактурно-сценічних даних, тому вони спрямували свою співацьку діяльність на вокально-камерний спів. Концерти проводились у невеликих акустичних приміщеннях, де їхній спів звучно наповнював зал.

Одарка Бандрівська, видатна камерна співачка і педагог середини XX ст. усвоїй праці “Особливості виконання камерних творів” надає великого значення артистично-стильовому смаку камерного виконавця, його загальній ліричній культурі та деталізації всіх елементів фактури та виражальних засобів, проте вона все-таки надає перевагу оперним співакам, які на відміну від камерних наділені міцнішим голосом, фактурно-сценічними даними, а також фізіологічним станом здоров'я $[1,61]$.
Виконання камерного репертуару потребує багатьох чинників, оскільки кожний твір являе собою стиснуту опрацьовану мініатюру, наповнену великим змістом, недостатньо готової форми, тоді потрібна прискіплива, осмислена робота, чіткий план виконання. Досить часто камерні концерти оперних співаків не відзначаються творчою спрямованістю. Такі співаки здебільшого обмежуються вокальнотехнічною стороною виконання, а інтерпретацію підміняють непереконливим пафосом або ілюстративністю жестів. Для камерного співу потрібні тонкі вокальні барви, стилістична градація і разом з тим природне, вільне і повнокровне звучання.

Глибокий аналіз оперативних можливостей виконавця дозволяє йому засобами свого мистецтва розкривати художні образи вокальної музики. Для втілення ролі в опері співак має декілька актів, протягом яких він може різнобічно виявити характер дійової особи, а романс виконується менше ніж, навіть $1-2$ хвилини, але за цей короткий проміжок часу він має відтворити в ньому все, що задумав автор твору

Романс виникає перед слухачем без усілякого попереднього сюжетного розвитку. Тим не менше романс має визначну і тонко побудовану форму 3 іiі розвитком і кульмінацією. Він має бути виконаний так майстерно, щоб надовго залишитись у пам'яті і серці слухача. Виконання романсу потребуе від співака високого артистизму, належної вокальної техніки, гострого сприйняття і втілення музичної форми. При дотриманні всіх перелічених вимог педагог повинен вимагати від студента тонкого нюансування при використанні емоційно-звукових барв. Якщо оперна партія потребує (при умовному порівнянні з живописом) насичених олійних фарб для зображення художнього образу, то для художніх образів камерної музики потрібно вміти користуватись фарбами “акварельними”.

Зрозуміло, що на початкових стадіях навчання не варто давати студентам твори 3 надто великою емоційною насиченістю, щоб не зашкодити рівновазі з технічним оформленням звуку. Від самого початку навчання не варто практикувати навчання як формальне вокалізування 3 текстом, щоб подолати вокально-технічні перешкоди, але щоб і не втратити емоційне і творче виконання [5, 131].

Емоційний стан при виконані кожного 
вокального твору, який напрацьовується в класі, сприяє емоційному забарвленню звуку, що відповідає характеру даного твору. Особливо важливо враховувати, щоб емоційний настрій супроводжував співака не тільки під час виконання твору на академічному концерті, а також під час роботи над твором на початковому етапі.

Слід зазначати, що на глибину вияву емоційного компоненту у звуковій барві впливає стиль даного твору. Зрозуміло, що твори доби романтизму потребують значно яскравішої емоційної палітри ніж, припустимо, твори, навіть з подібним змістом, доби бароко. Дещо більша емоційна гнучкість притаманна сучасній вокальній музиці, виконання якої допускає довільне індивідуальне емоційнозвукове трактування забарвлення у межах широкого тембрального спектру. Чисельна література 3 проблем вокальної педагогіки віддзеркалює рівень уваги, яка приділяється в учбовому процесі емоційному аспекту вокальної емісії. Деякі педагоги пропонують певну послідовність у навчанні співу, залишаючи для втілення художніх завдань лише кінцеву стадію постановки голосу, інші наполягають на тому, що емоційний стан співу сприяє встановленню вокально-технічних якостей голосу. Від розуміння співаком змісту твору в цілому, фрази і слова в значній мірі залежить його фонетична організація, яка висловлює почуття і гаму відтінків емоційного стану виконавця. Удосконалюючи вокальну техніку, слід прищеплювати студенту відчуття правди звуку, можливість відчувати кожний звук як художню правду. Не слід розмежовувати навчальний процес на окремі елементи - це найчастіше загальмовує розвиток співака. Дуже важливим моментом на початковому етапі є спів творів з різноманітною насиченістю. Такий підхід до постановки голосу полягає в тому, щоб педагог, прагнучи до удосконалення вокальної фонації, не позбавляв звукоугворення, природного емоційного забарвлення, а прищеплював вміння свідомо нюансувати тембр співу відповідно до поставленого художньо-емоційного завдання. Справжня вокально-камерна музика ніколи не несе в собі байдужості та приземленості. Вона уникає побутової буденності, сірої життєвої достовірності. Спів без високої духовної зарядки позбавлений смислу, він, по суті, нікому не потрібний. Знижений до побутової оповіді спів це та ж побутова, часто недорікувата мова, незважаючи на те, що ії покладено на музику і як вже неодноразово підкреслювалося в статті, що не потрібно шукати в голосі лише красу та блиск, а з усією наполегливістю розвивати виражальні властивості голосу $[2,89]$.
У виконавській роботі необхідно відрізняти два основних компоненти:

1) Емоційно-психологічна сторона-розуміння стилю і характеру виконання твору, внесення в художній образ даного твору творчого настрою, яскраву виразність виконання.

2) Підбір камерного репертуару, куди входить не тільки бездоганне знання мелодії ритму і тексту твору, а також володіння всіма вокальнотехнічними засобами, необхідними для виконання даного твору.

Ці два компоненти мають тісний зв'язок і взаємодію. Емоційно-психологічна сторона, свідоме проникнення в характер художнього образу потребує від виконавця відповідних вокальних фарб, необхідних для втілення цього образу. У цьому випадку технічна сторона володіння всім арсеналом вокально-технічних засобів надає виконанню велику виразність, яскравість, дохідливість.

Тільки гармонійний розвиток двох цих сторін дає можливість виконавцю досягнуги творчої майстерності, необхідних для розвитку камерного мистецтва.

До розуміння художніх завдань даного конкретного твору виконавець може прийти різними шляхами: інтелектуальним аналізом даного твору, класичним виконанням. Співак своїм виконавським відчуттям повинен відчувати, які необхідні фарби потребує характер музики даного твору; ці шляхи можугь поєднатися для досягнення тої чи іншої художньої мети. Коли це стане для нього навичкою, тоді він відчує повну творчу вільність. Неможливо запропонувати певні рецепти в роботі над підготовкою репертуару, так як в кожному конкретному випадку вони будуть індивідуальним і можуть бути зовсім різними. Хочеться вказати на деякі випадки, які $є$ загальними в виконавській практиці молодих співаків:

1) Найчастіше зустрічається недолік: неточне вивчення авторського тексту. Якщо звуковисотний рисунок відтворюється точно, то до ритмічного рисунку співак часто відноситься неохайно і дозволяє собі значні вільності. Особливі труднощі зустрічаються, коли в мелодії і в супроводі зміщуються двох-трьохдольні розміри. Необхідно також бути дуже уважним до пауз та пам'ятати що їх також “треба співати”, знімати звук точно тоді, як це вказує автор, не перетвоюючи паузу у відпочинок для голосу, а наповнювати їі внутрішнім змістом; теж особливо погано тоді, коли співак продовжує тримати свою ноту, а в акомпанементі вже звучить інша гармонія. Також неприпустимо зловживання ферматою 3 метою показати свої голосові можливості, а використовувати ії лише тоді, коли вона не порушує 
музичний задум. Всі вказівки композитора вказаний темп, сила звука, фразові ліги, паузи, синкопи - являються знаками, без яких неможлива правильна інтерпретація твору. Однак точне вивчення авторського тексту не повинно бути сліпим, бездумним копіюванням. Виконавець завжди являється співавтором композитора, він повинен глибоко продумати, відчути, творчо сприйняти авторський задум і разом 3 тим строго укластися в ці рамки, які пропонує йому автор. Ми знаємо також багато прикладів, коли виконавці вносили в авторський задум свої зміни, які пізніше ставали вже неначе традицією і в нікого не викликали сумнівів. Разом 3 цим це не знімає основних вимог до виконавця - точно притримуватись авторського тексту.

2) По-друге, нерідко зустрічається недолік у молодих співаків щодо чисто вокальної області. Це недостатня увага до резонування в цілому до однорідності звучання голосних. Співаку необхідно при вспівуванні твору дуже точно і прискіпливо слідкувати за тим, щоб всі звуки, які входять в даний твір, неоднаково резонували, щоб між фразами не траплялись пусті, тусклі, незвучні ноти, щоб всі голосні у слові були належно звучні. Неоднорідність звучання особливо помітна в тих випадках, коли на одній ноті вимовляється декілька голосних. Буває дуже неприємно, коли після двох темних, прикритих голосних “у” i “ю” недосвідчений співак забагато “висвітлює” голосну, а вона втрачає округленість звучання i не буде добре резонувати або навпаки - голосні “у” і “ю” будуть звучати перекрито і глибоко по відношенню щодо добре резонованої “а”. У таких випадках потрібно добре працювати над рівністю резонування різних голосних. Це в цілому не означає, що їх потрібно знівелювати, тобто замінити кожну з них іiі характерним звучанням. Туг мається на увазі характер і місце їх резонування. При однорідному звучанні всіх голосних змістовний акцент повинен бути обов'язково виділений і підкреслений трішки більшою силою звуку, тоді як на голосних складах особливо в кінці слів, необхідно трохи забрати силу звучання.

3) Варто ще звернути увагу співаків на підготовку високих або незручних для них нот. Якщо трапляється така нота, і якщо іiї важко атакувати окремо, особливо від попередньої, завдання значно полегшує в таких випадках розцінювання попередніх нот як трампліну, так як для верхньої. Це нота - трамплін повинна бути взята точно в тій же манері, як була взята i попередня важка нота. Потрібно підготувати, i місце звучання, і положення рота. Якщо є належна правильна підготовка, вона відтвориться сама собою. Співак завжди повинен підходити до важкого місця з розумінням того, що він повинен робити, щоб справитися з ним, а не співати без всякої підготовки і робити часто протилежне. Значно допомагає забезпеченню доброго звучання високої і незручної ноти чітке виспівування попередньої приголосної.

4) Молоді виконавці часто неуважні до слова у співі при вимовленні приголосних. Питання про дикцію, як одне із компонентів вокального мистецтва, не може бути вичерпне у даній статті, та як воно дуже обширне. Приголосні являються ніби “оправою” для голосних, їх чіткість в значній мірі створює красиве звучання голосної. Особливо пильним треба бути при подвійних приголосних, а також у тих випадках, коли попереднє слово закінчується на ту саму приголосну, з якої починається наступне, в цих випадках дуже часто пропадає одна $з$ приголосних.

5) Часто молоді співаки не дають належної уваги виконанню двох або декількох пов'язаних лігою нот, які входять в один склад тексту. В такому випадку потрібно зробити легке portamento 3 першої ноти на другу, не допускати, щоб вона звучала голосніше першої і в ніякому разі не допускати придихання. Застосовувати легке portamento на злігованих нотах співаки часто забувають, а між тим це дуже красиво і допомагає у виробленні доброї кантилени $[4,91]$

Виконання камерно-вокальних творів, значно розвиває співака, розширює його музичний кругозір, сприяє його внутрішньому збагаченню, дає йомуможливість володіти новими вокальними фарбами. По виконавській манері, по культурі слова, музичній фразі, по глибині відчуття образу зразу можна зрозуміти, наскільки ознайомлений співак з камерною літературою.

Виконання камерного репертуару багато потребує, тут кожний твір являє собою стислу, ніби відшліфованумініатюру, наповнену великим змістом і туг не обійтись готовою формою: потрібна велика вдумлива робота: від великої загальної культури, до творчої самостійності навчитися не тільки співати, але і творчо опанувати твір.

Дуже часто камерні концерти співаків мають рівень жалюгідних виступів з заспіваним репертуаром, який не відповідає творчому напряму. Такі співаки, як правило, обмежуються вокально-технічною стороною виконання, а інтерпретацію заміняють фальшивим пафосом або ілюстрацією рухів, жестів.

Для камерного співу необхідні тонкі вокальні фарби, різноманітна на стилістика і разом $з$ тим природний, вільний, повноцінний звук [3, 22].

Суть музичних ефектів у виконанні камерного 
твору полягає в їх різноманітності у застосуванні конкретних контрастних зіставлень, а джерело їх невичерпне. Але ступінь нюансування залежить від розуміння, відчуття образу, від смакуі культури виконавця. Не можна співати мляво, безбарвно, але і не треба надмірно пересилювати себе. Спів повинен бути простим, ритмічним, вдумливим відповідно до змісту даного твору. Вивчаючи нові твори, не потрібно співати на повний голос, а робочим звуком, напівголосно, але на повному диханні. Крайні ноти зовсім не треба брати повним голосом, а тоді, коли співак буде знати добре мелодію всього твору. До початку вивчення твору слід довідатись, хто автор слів, музики, коли написаний твір, яка епоха у ньому замальовується.

Творча уява - одне 3 головних засобів виконавця. Уявити - значить побачити ясно і конкретно образ у ціломуі в найменших дрібницях (паузу, жест, вираз обличчя, очей). Проте щоб правильно змальовувати собі зовнішній вигляд людини, треба добре уявити і ії нутро. Роль уяви у створенні сценічних образів велика і значна, вона дає виконавцю можливість оволодіти образом характеру творів, вільно творити, тримати себе на сцені. Виконавцю потрібна ще одна якість: він мусить бути твердо впевнений в тому, в чому хоче переконати слухача і глядача. У виконавській діяльності є ще важливий елемент: жест. Навіть незначний рух очей, руки, брів повинен бути правдивим. Виконавець завжди повинен пам'ятати, що на сцені кожен рух корпусу, його міміка обличчя, жест рук помітний глядачу. Який би не був хороший голос співака, його зовнішність, вміння триматися на сцені, вихід - завжди впливає на глядача і сприяє успіху. У деяких співаків $\epsilon$ звичка виходити на сцену 3 серйозним без настрою виглядом. Треба старатися позбавитися цього. Ніщо так не псує глядачеві настрій, як похмурий, непривітний вигляд обличчя співака. Слід пам'ятати, що глядач прийшов відпочити. Якщо у вас від природи сильний голос, не треба старатися здивувати глядача силою звуку, а навпаки добиватися ефектів при допомозі "pianissimo i mezza voce", що більше впливає на розуміючу аудиторію. Спів не повинен бути одноманітним, тому потрібно постійно чередувати piano i forte. Якщо доводиться співати в поганих умовах акустики, не потрібно форсувати звук, в цьому випадку можна в певній мірі підсилити звучність голосу, використовуючи резонатор: “так звану маску”. Це єдиний спосіб подолати погану акустику. Ми знаємо, що співається добре, коли $є$ бажання співати. Але співати доводиться не тільки тоді, коли хочеться, а коли треба, тому важливо вміти керувати своїм настроєм i психологічним станом. Всі технічні труднощі: високі ноти, філіровка звуку потребують вільної і точної роботи м'язів, яка залежить насамперед від нервової системи. Співак повинен розбиратись у своємуголосовому механізмі і на слух відрізняти, яка нота правильна, а яка невірна, вміти фіксувати звучання і виправляти погане. Атака звуку на forte i piano, а також беручи високі ноти, співак повинен вірити, що все буде саме так, як він це бажає. Ніколи не потрібно вагатися, бо в такомуразі м'язи не відтворять необхідної активності, і голос звучатиме погано, але не можна самовдоволено заспокоюватися на досягнутому, а навпаки добиватись більшого і прагнути до кращого. Праця - єдиний шлях, яким треба йти, а енергія, воля і дисципліна - джерела, з яких виконавець черпає свою майстерність. Слід пам'ятати, що виконання вокального твору тільки тоді може буги правдивим, коли співак зуміє розкрити органічно і поєднати разом двох авторів: композитора і поета.

Висновки. Добре систематизований підбір камерного репертуару є одним 3 важливих моментів у роботі 3 молодими співаками. Вокальний репертуар повинен служити основою у розвитку музично-художнього смаку та у вдосконаленні вокально-технічними навичками.

\section{ЛІТЕРАТУРА}

1. Бандрівська О. Особливості викладання камерних вокальних творів. Науково-методичні праці, статті, рецензії / Упор. Р. Мисько-Пасічник. Львів, 2002. С.61-88.

2. Євтушенко Д. Роздуми про голос. Київ, 1979. 89c.

3. Луканин В. Обучение и воспитание молодого певца. Ленинград, 1977.85 с.

4. Михайлова Т. Вопросы вокальной педагогики. Москва, 1967. 149 с.

5. Мотт-Заботина Н. Вопросы вокальной педагогики Москва, 1962.145 c.

\section{REFERENCES}

1. Bandrivska, O. (2002). Osoblyvosti vykladannia kamernykh vokalnykh tvoriv [Features of teaching chamber vocal works]. Scientific and methodological works, articles, reviews. (Ed.). R. Mysko-Pasichnyk. Lviv, pp.61-88. [in Ukrainian].

2. Ievtushenko, D. (1979). Rozdumy pro holos [Reflections on the voice]. Kyiv, 89 p. [in Ukrainian].

3. Lukanin, V. (1977). Obuchenie $i$ vospitanie molodogo pevtsa [Training and education of young singing]. Leningrad, 85 p. [in Russian].

4. Mikhaylova, T. (1967).Voprosy vokalnoy pedagogiki [Questions of vocal pedagogy]. Moscov, 149p. [in Russian].

5. Mott-Zabotina, N. (1962). Voprosy vokalnoy pedagogiki [Questions of vocal pedagogy]. Moscov, $145 \mathrm{p}$. [in Russian].

Стаття надійшла до редакції 28.02.2019 